\title{
SPIRITUALITY AND THE HERMENEUTICS OF FAITH
}

\section{Author:}

Vincent Brümmer

\section{Affiliation: \\ ${ }^{1}$ Department Systematic \\ Theology, University of}

Stellenbosch, South Africa

\section{Correspondence to}

Vincent Brümmer

email:

vincent.brummer@gmail.com

\section{Postal address:}

Valklaan 1, 3722ZJ,

Bilthoven, The

Netherlands

\section{Keywords:}

Hermeneutics of faith nature of faith; religious experience; Spirituality

Dates:

Received: 23 Apr. 2009

Accepted: 08 Jan. 2010

Published: 05 Nov. 2010

How to cite this article:

Brümmer, V., 2010,

'Spirituality and the

hermeneutics of faith',

HTS Teologiese Studies/

Theological Studies 66(1),

Art. \#891, 5 pages. DOI:

10.4102/hts.v66i1.891

\section{This article is available}

at:

http://www.hts.org.za

\section{Note:}

Prof. Dr Vincent Brümmer

is participating as

a research fellow at

Stellenbosch University, Stellenbosch, South Africa
(C) 2010. The Authors. Licensee: OpenJournals Publishing. This work is licensed under the Creative Commons Attribution License.

\section{ABSTRACT}

The first part of this essay argues that religious experience should not be viewed as an extraordinary kind of extra-sensory perception (visions, ecstasies etc) but as 'hermeneutical' in the sense that it entails an interpretation of our ordinary experience (including ordinary senseperception) or sometimes of particularly impressive experiences of the world and of our lives in the light of faith. The heritage of faith in a religious tradition provides believers with a framework of understanding in terms of which they can look on things with the eyes of faith. Various key features of this kind of interpretation are explained. The second part of the essay shows how various forms of spirituality are ways in which believers are trained in looking on life and the world with the eyes of faith and explains what this entails for the life of faith.

\section{THE HERMENEUTICS OF FAITH}

Hermeneutics is the art of interpretation. We interpret things in order to understand what they mean. In this way we interpret texts, including religious texts like the Bible, in order to understand the meaning of what is written in these texts. Since such religious texts are the fundamental sources of religious traditions, the interpretation of such texts is of great importance for the faith of believers who live their lives in accordance with these traditions.

However, we do not only interpret texts. We also interpret our experience of the world and of our own lives in order to understand what they mean. In this way religious believers understand the meaning of their lives and the world in the light of their faith. They look on life and the world with the eyes of faith and this way of looking determines the meaning that life and the world has for them. Faith itself is therefore a form of interpretation. In this sense faith is 'hermeneutical.'

A good illustration of what it means to look on life and the world with the eyes of faith can be found in the vision of St. Francis of Assisi as described by G.K. Chesterton:

If a man saw the world upside down, with all the trees and towers hanging head downwards as in a pool, one effect would be to emphasize the idea of dependence... If St. Francis had seen, in one of his strange dreams, the town of Assisi upside down, it need not have differed in a single detail from itself except in being entirely the other way around. But the point is this: that whereas to the normal eye the large masonry of its walls or the massive foundations of its watch-towers and its high citadel would make it seem safer and more permanent, the moment it was turned over the very same weight would make it seem more helpless and more in peril. It is but a symbol; but it happens to fit the psychological fact. St. Francis might love his little town as much as before, or more than before; but the nature of the love would be altered even in being increased. He might see and love every tile on the steep roofs or every bird on the battlements; but he would see them all in a new divine light of eternal danger and dependence. Instead of being merely proud of his strong city because it could not be moved, he would be thankful to God Almighty that it had not been dropped; he would be thankful to God for not dropping the whole cosmos like a vast crystal to be shattered into falling stars... He who has seen the whole world hanging on a hair of the mercy of God has seen the truth; we might almost say the cold truth. He who has seen the vision of his city upside down has seen it the right way up.

(Chesterton 1957:74-75, 78)

This example illustrates a number of important features of the hermeneutics of faith:

1. St Francis, like believers in all theistic traditions, understood the meaning of things by looking on them with the eyes of faith and thus relating them to God. This has important implications for the way in which we are to understand the nature of religious experience. Such experience should not be viewed as an extraordinary kind of extra-sensory perception, but rather as ordinary experience (including ordinary sense perception) looked upon with the eyes of faith. St. Francis did not merely observe his little city lying on the hillside. With the eyes of faith he also discerned how its very existence is dependent on the grace of God. In this way believers understand their own lives and actions, the sensory world in which they live and act, as well as events in the contemporary world and in history, in the light of their faith. Thus I experience my own life as a life of fellowship with God, the sensory world as an expression of the grace and glory of God, and events in the world as either realizations of God's intentions (and therefore good) or as contrary to the will of God (and therefore evil). So too I can look on events in history and in my own experience as providential or revelatory actions of God. It is only with the eyes of faith that I can experience an event as a manifestation of God's providential care or can discern the revelation of God in a vision or a book or a sermon. Religious experience is therefore 'hermeneutical' in the sense that it entails an interpretation of our ordinary experience or sometimes of particularly impressive experiences of the world and of our own lives in the light of faith.

2. Looking on things with the eyes of faith involves interpreting them in the light of the heritage of faith handed down in a religious tradition. St. Francis did not merely become aware of the dependence and lack of permanence of his little city. In the light of the heritage of faith handed down to him in the Christian tradition, he understood this as dependence on the grace of God. The heritage of faith provided him with a framework of understanding in terms of which he could look on things with the eyes of faith. 
3. This way of looking determined the meaning that his little city had for him. Assisi, like the whole cosmos, is not selfsufficient. It is dependent on the grace of God for not being dropped 'like a vast crystal to be shattered into falling stars.' Like the Cosmos as a whole, Assisi does not have its meaning in itself. It derives its meaning from the way it is related to God. Because it is dependent for its very existence on God, it is not merely good and dear to the heart of St. Francis. Its continued existence is now seen as a gift from God and thus it has a new meaning for St. Francis. In the words of Chesterton: 'all goods look better when they look like gifts' (Chesterton 1954:78). In the words quoted above: 'St. Francis might love his little town as much as before, or more than before; but the nature of the love would be altered even in being increased'

4. The meaning of things determines the attitude that we should adopt towards them and the actions that are appropriate in relation to them. 'Instead of being merely proud of his strong city because it could not be moved, he would be thankful to God Almighty that it had not been dropped.' In this sense faith is not only a way of looking but also a way of living. Seeing life and the world as dependent on God entails a life of gratitude rather than a life of complacency or self-sufficiency. Religious experience is transforming. It not only transforms the way we look at things but also our attitudes and actions in relation to them. It transforms our lives and not only our understanding.

5. Believers claim that that their interpretation is true. It is not merely a useful fiction or an illusion. The eyes of faith reveal to them the truth about reality. 'He who has seen the whole world hanging on a hair of the mercy of God has seen the truth; we might almost say the cold truth. He who has seen the vision of his city upside down has seen it the right way up.'

6. This way of looking is not shared by everybody. In a secular culture, many people try to understand the meaning of the world in secular or 'worldly' terms. The world derives its meaning from itself. Faith is an alternative way of looking and bestows a different meaning on the world than the meaning that the world has for the secularist. 'Whereas to the normal [secular] eye the large masonry of its walls or the massive foundations of its watch-towers and its high citadel would make [Assisi] seem safer and more permanent, the moment it was turned over the very same weight would make it seem more helpless and more in peril.'

7. This kind of understanding does not come naturally to us. In the words of John Calvin,

with regard to the knowledge of God, the knowledge of his paternal favour, which constitutes our salvation .... the most ingenious are blinder than moles. ... Their discernment was not such as to direct them to the truth, far less to enable them to attain it, but resembles that of the bewildered traveller, who sees the flash of lightning glance far and wide for a moment, and then vanish into the darkness of the night, before he can advance a single step.

(Calvin, 2.2.18)

I think that Calvin is rather optimistic here. Most of his travellers today are not even aware of the fact that they are bewildered! Even the flash of lightning remains hidden from them. Seeing the world with the eyes of faith therefore requires spiritual training. Through lifelong spiritual training St. Francis had grown sensitive to the ways in which his own life and the world in which he lived were related to God. Such training enabled him to discern the presence of God with the eyes of faith. What is the nature of such spiritual training?

\section{SPIRITUALITY}

In the Bible the Holy Spirit is held to be the primary agent of our spirituality and our religious experience. It is only through enlightenment by the Spirit that we are able to see things with the eyes of faith. Thus in John 16:13 Jesus refers to the Holy Spirit as 'the Spirit of truth' who 'will guide you into all the truth.' In the words of John Calvin,

It is when the Spirit, with a wondrous and special energy, forms the ear to hear and the mind to understand. ... It thus appears that none can enter into the Kingdom of God save those whose minds have been renewed by the enlightenment of the Holy Spirit.

(Calvin, 2.2.20)

The claim that the Spirit is the primary agent of our religious experience is not a simple empirical fact. It is itself the fruit of religious experience and the hermeneutics of faith. It is only with the eyes of faith that we can recognise our religious experience to be a gift of the Spirit and not something of our own making. However, this recognition does not entail that we are merely passive recipients of such experiences. The Spirit may be the primary agent of our experience, but then the primary agent always works through the secondary agency that we provide. God acts in the things we do. ${ }^{1}$ The Spirit provides the necessary conditions for as well as the fruits of our spiritual endeavours. This does not make these endeavours superfluous, however.

It is at this point that the role of spirituality as a form of spiritual training comes in. Spirituality can be defined partly as a form of training in religious experience. In our spirituality we are trained to see our lives and experience of the world with the eyes of faith. Alhonsaari explains this point as follows,

When praying, the believer is ... repeatedly making himself see the world in a certain way in which everyday experiences are fitted into what he thinks is the proper reality; he is repeatedly bending his emotional life and his behaviour to conform to this reality.

(Alhonsaari 1973:47-48)

In different forms of prayer we consciously face up to various aspects of our life in fellowship with God, and in this way train ourselves to experience life and the world in terms of this fellowship. Thus in petition we face up to our own dependence on God and so come to experience the providential actions of God on which we depend. As Peter Vermiglius points out, believers 'frequently take time for prayers, for that is what it means to perceive the providence of God' (cited Ritschl (1982:282)). In intercession we face up to our own concern (or lack of concern) for the needs of others and come to experience this in terms of our fellowship (or lack of fellowship) with God. In penitence we come to look upon our own failings as sins in which our fellowship with God is being marred. In prayers of dedication we become aware of our own commitment (or lack of commitment) to doing God's will. In praise we look upon the world as an expression of God's goodness, holiness and glory. In thanksgiving we look upon our own capacities and opportunities and the fulfillment of our needs as gracious gifts from God. In this sense prayer is a form of meditation in which we consciously train ourselves to experience the ways in which we relate to God, to ourselves, to the world and to other people in our actions and attitudes in terms of our faith. In this way prayer is, in the words of John Drury, a 'school of seeing' (Drury 1972: Chapter 2). Of course this does not only apply to prayer but also more generally to liturgy and to all forms of spirituality.

Spirituality and religious experience also have a lifetransforming moral dimension. They do not only determine the way we experience our lives and the world in which we live, but also our actions and attitudes in relation to our lives and the world. I cannot experience my life as fellowship with God without acting in fellowship with God. I cannot experience events in the world as realizations of God's perfect intentions without committing myself to furthering the occurrence of such events, and I cannot experience events as contrary to the divine will without opposing them in my actions and attitudes. Thus, spirituality is not merely a school of seeing but also a school of

1.For a detailed analysis of this 'double agency', cf. Brümmer (2006), Chapters 26 and 31. 
doing. In the words of Alhonsaari quoted above, spirituality is not merely a way in which we repeatedly make ourselves 'see the world in a certain way' but also repeatedly 'bend our emotional life and our behaviour' to conform to this way of seeing. Faith is not merely a way of seeing but also a way of living and acting. Hence spirituality has not only to train believers in religious experience. It should also further the sanctification of their lives in fellowship with God.

However, its significance goes further than merely being a means to this end. In spirituality believers practice their fellowship with God. They are not merely practicing for it. The practice of spirituality is not like practicing swimming strokes without going into the water. In the exercise of spirituality believers aim at really establishing, restoring and acknowledging their fellowship with God and bending their attitudes and actions accordingly. The relation between spirituality and the moral life of the believer is therefore an internal one in the sense that spirituality and the life of fellowship with God are impossible without each other. ${ }^{2}$

Clearly then, religious belief is primarily a way of seeing as well as a way of living in accordance with this way of seeing. Spirituality is both a way of expressing and a way of training ourselves in this way of seeing and living. This does not mean, however, that religious belief has merely expressive and commissive force. On the contrary, it also has a constative force since the way of seeing it expresses and the way of life to which it commits the believer, entail a specific understanding of reality which is constitutive for both the way of seeing and the way of life. Wittgenstein argues that all forms of life are constituted by tacit presuppositions about reality. ${ }^{3}$ This also applies to the form of life of Christian spirituality. Thus I logically cannot claim to live a life of fellowship with God without assuming that God exists and is the kind of personal being with whom such fellowship is possible. Since such tacit presuppositions about God are constitutive for Christian spirituality, the latter becomes incoherent if these presuppositions are denied. R.W. Hepburn explains this point as follows.

If I say 'The Lord is my strength and shield', and if I am a believer, I may experience feelings of exultation and be confirmed in an attitude of quiet confidence. If, however, I tell myself that the arousal of such feelings and confirming of attitude is the function of the sentence, that despite appearances it does not refer to a state of affairs, then the more I reflect on this the less I shall exult and the less appropriate my attitude will seem. For there was no magic in the sentence by virtue of which it mediated feelings and confirmed attitudes: these were responses to the kind of Being to whom, I trusted, the sentence referred: and response is possible only so long as that exists to which or to whom the response is made.

(Hepburn 1957:148)

Within the language-game of Christian spirituality, such constitutive presuppositions cannot be doubted or denied since that would entail abandoning the language-game as such. In this sense I agree with J.N. Findley's contention that for the believer partaking in a religious form of life,

God's non-existence must be wholly unthinkable in any circumstances. There must, in short, be no conceivable alternative to an existence properly called 'divine': God must be wholly inescapable ... whether for thought or reality.

(Findley 1955:52)

This has important implications for the nature of religious doubt. Such doubt is not intellectual doubt about the truth of a hypothesis but existential doubt about the adequacy of a religious form of life and a religious way of understanding life and the world. It is not doubt of the mind but doubt of the heart. It does not call for an argument proving the truth of the hypothesis that God exists but rather a creative attempt to show that the heritage of a religious tradition can be conceptualised in a way that is adequate to the existential demands of life. We will return to this point below.

2.For a more extended analysis of the relationship of prayer and spirituality to the moral life of believers, see Chapter 7 of Brümmer (2008).

3.For an extended discussion of this point, see Chapter 10 of Brümmer (2008).
The constative claims about God, that are constitutive for Christian spirituality, do seem to raise a problem concerning the limits of our language. If all our human language is creaturely in its reference and if God is wholly other from his creatures, it seems to follow that anything we say about God fails to apply and whatever we say about God remains inadequate. This raises fears that if we were to relate to a God about whom we can talk, we risk loving a mere human construction of our wishful thoughts. That seems to entail that we should be apophatic about the constitutive presuppositions of our spirituality. ${ }^{4}$

I agree that, since God is very unlike his creatures, our creaturely language is inadequate in the sense that it cannot be applied to God in a straightforward sense. More specifically, if Christian spirituality is one of personal fellowship with God, we will have to use personal language in order to express the constitutive presuppositions of this spirituality. However, since God is not like other people, the personal terms used to talk about God cannot have the same meaning that they have with reference to other people and our relations with them. Our language about God is therefore metaphorical in the sense that not all the implications that this language has with reference to other people can be carried over to our talk about God. ${ }^{5}$ Here Wittgenstein points out that, in order to partake in a religious form of life like that of Christian spirituality, we need to be introduced into the language-game expressing it and into the use of the metaphors and conceptual models that characterize it. In this connection Wittgenstein (1966:63, 71-72) says that we have to learn 'the technique of using a picture'. This involves learning the logical limits of the languagegame and of the use of the pictures employed in it. These logical limits refer to the inferences, which can or cannot be validly drawn from the picture within the religious language-game. I master the technique of using the picture when I know which inferences I can and which I cannot draw from it. Wittgenstein illustrates this point in the light of the picture: 'God's eye sees everything.' What inferences could a believer draw from this picture, and what inferences would be invalid within the religious languagegame? Obviously, a believer would say that, since God's eye sees everything, God is aware of all that happens, not only in the world but also in the hearts and minds of all people: 'Almighty God, unto whom all hearts be open, all desires known, and from whom no secrets are hidden ...' However, Wittgenstein asks the rhetorical question: 'Are eyebrows going to be talked of, in connection with the eye of God?' (Wittgenstein 1996:71). Here we have clearly reached the logical limits of the picture. It is conceivable that a child might ask after the eyebrows of God. It is however part of the child's introduction to the religious language-game to learn that such a question is out of order since it transgresses the logical limits of the language-game.

Two important clues to these logical limits are the following. First of all, God is an infinite being and not subject to the limitations of creaturely existence. Thus his knowledge and power, his love and ability to do good, are not limited in the way ours are. The personal terms we use with reference to God and our relations with God should therefore be qualified in order to eliminate all implications of human finitude in God. ${ }^{6}$ Secondly, what we need to say about God is limited to the constitutive presuppositions of our spirituality. All implications of personal language, which are not relevant to these presuppositions, are therefore also to be avoided. Thus the claim that God can see into our hearts and know all our thoughts and desires so that we cannot keep these secret from him, is very relevant for our spirituality, whereas implications about eyebrows are not. In this sense all talk about God is necessarily existential in the sense that it refers to the constitutive presuppositions of our spirituality. This excludes all intellectual speculation about how God is apart from the way we

4.On this point cf. Chapter 1 of Brümmer (2005) and Chapter 2 of Brümmer (1992).

5.For a more detailed discussion of the metaphorical nature of our God-talk, see Chapter 13 of Brümmer (2006).

6.In Chapter 7 of Brümmer (1993) I explored these limits of the concept of love with reference to God. 
relate to God in our spirituality and in the life of faith. Here are the logical limits of our God-talk. Beyond this point we can only be agnostic and apophatic. Here God 'dwells in unapproachable light' (I Tim 6:16). Within these limits, however, we cannot afford to be apophatic. Our spirituality and our fellowship with God are human and therefore we must be able to spell out the constitutive presuppositions of this spirituality and of this life of fellowship in human terms or else our spirituality and fellowship with God would collapse into an incomprehensible something we know not what. If we were to claim that also within these limits everything we say about God fails anyway, then our spirituality of fellowship with God will fail also. Spirituality would then be reduced to mere vague feelings of ecstacy that cannot be expressed in words.

To be apophatic at this point leads to an unacceptable ontological vagueness. The more apophatically vague the constitutive presuppositions of our spirituality become, the more such spirituality is divorced from the concrete faith of a religious tradition. Spirituality is then reduced to a therapeutic technique by means of which we try to attain ecstatic experiences or a holistically 'healthy life'. Spirituality then becomes one of the commodities on offer in the market-place of spiritual goods where every individual can put together his or her own syncretistic cocktail of techniques for improving the quality of life and experience.

Religious spirituality requires a community of believers. An individualised spirituality must fail in two ways. First of all, it is intolerably isolating, walling the self off into a kind of spiritual autism. It is as if the self, deprived of a real calling to community beyond itself, becomes the prisoner of its own anxieties and doubts. An individualized spirituality therefore fails to make us happy. However, it also fails to be a religious spirituality. As we have shown above, religious experience consists of seeing things with the eyes of faith. This presupposes faith, however, and is impossible when the claims of faith become apophatically vague. Furthermore, this faith is not something, which the individual believer can invent for him- or herself. Nor is it something, which somehow descends upon the individual believer directly from heaven. It is a heritage of faith handed down by a community of believers who participate in a common tradition. Without participation in this tradition, religious experience and spirituality become impossible.

It is clear that religious spirituality is based upon the heritage of faith mediated by the community of believers. However, this community remains a community of sinners who, as Augustine would say, is never free from concupiscentia, superbia and amor sui. For this reason the heritage of faith which they hand down to us remains a treasure in earthen vessels. It is never infallible nor immutable and beyond critical reappraisal and reinterpretation. For this reason the spirituality based on it is not immune from becoming pathological. Our spirituality can go wrong in two ways: through lack of intensity (or richness) and through lack of extensity (or reach)

Our spirituality can suffer from a lack of intensity or richness when we treat the heritage of faith as a theory and fail to internalize it in our lives. Spirituality then affects our minds rather than our hearts. Here the words of Chesterton (1957:16) about St. Francis apply: 'For this great mystic his religion was not a thing like a theory but a thing like a love-affair.' Our spirituality loses its intensity when it is turned into a theory rather than a life of loving fellowship with God. The tendency to intellectualise the faith is characteristic for modernity in its the thirst for extending our objective scientific knowledge of reality. Modernity reduces human thought to its epistemic dimensions. In this way we tend to think of reality as merely the object of knowledge rather than the context for meaningful action, and we ourselves become mere epistemic subjects rather than the agents of meaningful living. ${ }^{7}$ Christianity then becomes for us a theory to be studied rather than a form of life to be lived. It is here that we require the training of spirituality described above. We must learn to see ourselves and our world with the eyes of faith in order that within the world we might come to live the life of fellowship with God. Only then can spirituality regain its richness or intensity.

The other way in which our spirituality can go wrong is through lack of extensity or reach. In various historical and geographical situations human beings are faced with widely differing challenges and demands of life. It is here that our spirituality should have the necessary extensity or reach in order to make sense of all the concrete contexts of life and the ever varying demands with which we have to deal. Our spirituality fails if it is unable to connect with the variety of situations in which human beings find themselves. It is here that we should remind ourselves that the heritage of faith is not an immutable and finalized system of ideas, but is subject to constant change and reinterpretation as it is handed down in the course of the tradition. The heritage of faith is rather an inexhaustible fund of models and metaphors, stories and images, memories and assumptions, institutions and practices etc. from which we can derive and adapt what is needed to make sense of the context within which we live. In the words of Jesus: 'When a teacher of the law has become a learner in the kingdom of Heaven, he is like a householder who can produce from his store things new and old' (Mt13:52). The heritage of faith is an eternally adequate source but not an eternally immutable system. The heritage of a religious tradition is not a system of thought but a fund of metaphors and narratives, assumptions and injunctions that present to us various alternative 'constructions of reality'. The task of the 'teacher of the law' is not to combine these into one coherent and immutably true construction of reality which would remain valid for all time and all situations. But rather creatively to develop those which are most relevant and adequate to the situation in which we are called to live and act. We should not merely repeat the heritage of the tradition without change in its original historical form but should sometimes 'invent' new and relevant ways of understanding the heritage that could be incorporated coherently within the tradition. Often such an 'invented' tradition could provide the most effective and adequate forms of spirituality for our lives in situ.

In order to maintain the richness and reach of our spirituality, theology has an essential role to fulfill as critical and innovative reflection on the heritage of faith. Thus theologians are called upon to develop proposals for conceptualizing this heritage in ways that are relevant and adequate in the situation where we are called upon to live and act, intelligible and credible for the community of believers today, as well as coherent and in recognizable continuity with the tradition in which we stand and from which we live. ${ }^{8}$ However, even theologians are fallible humans and should therefore be modest in the claims they make! They can never produce the final and infallible conceptualization of the heritage of faith. In fact there can be no such thing as a final and infallible conceptualization which would remain immutably the same in all the changing situations in which we humans are called upon live and act. Even the ontological presuppositions of our spirituality and the image we have of the God with whom we seek fellowship in life, cannot be free from reappraisal and reinterpretation. After all, if we are to seek fellowship with a living God who is with us and surrounds us with his love in all the changing circumstances in which we find ourselves, then God cannot be an unchanging statue of stone but must be a living being who manifests himself in many ways depending on our needs and the challenges and demands we have to meet in fellowship with him. Theologians can therefore do no more than develop proposals or conceptual designs for the 
heritage of faith, which fulfill the criteria mentioned above. In the end each of us must see for him- of herself which of these proposals we can appropriate with integrity in the situation in which we live. At this level all faith and all spirituality is truly personal. In the words of Cantwell Smith (1978:191): 'My faith is an act that I make, myself, naked before God.' We can only pray that the God in whose presence we stand should inspire us by his Spirit that we might make this act in his truth.

\section{REFERENCES}

Alhonsaari, A., 1973, Prayer. An analysis of theological terminology, Luther Agricola, Helsinki.

Brümmer, V., 1992, Speaking of a personal God, Cambridge University Press, Cambridge.

Brümmer, V., 1993, The model of love, Cambridge University Press, Cambridge.

Brümmer, V., 2005, Atonement, Christology and the Trinity. Making sense of Christian doctrine, Ashgate, Aldershot.
Brümmer, V., 2006, Brümmer on meaning and the Christian faith: Collected writings of Vincent Brümmer, (Ashgate Contemporary Thinkers on Religion: Collected Works), Ashgate, Aldershot.

Brümmer, V., 2008, What are we doing when we pray? On prayer and the nature of faith, Ashgate, Aldershot.

Cantwell Smith, W., 1978, The meaning and end of religion, SPCK, London.

Chesterton, G.K., 1957, St. Francis of Assisi, Image, New York.

Calvin, J., 1953, Institutes of the Christian religion, trans. H. Beveridge, James Clarke and Co., London.

Drury, J., 1972, Angels and dirt. An enquiry into theology and prayer, Darton, Longman \& Tod, London.

Findley, J.N., 1955, 'Can God's existence be disproved?', in A. Flew \& A. MacIntyre (eds.), New Essays in Philosophical Theology, p. 52, SCM, London.

Hepburn, R.W., 1957, 'Poetry and religious belief', in A. MacIntyre (ed.), Metaphysical beliefs, p. 148, SCM, London.

Ritschl, A., 1972, Three essays, Fortress, Philadelphia.

Wittgenstein, L., 1996, Lectures and conversations on aesthetics, psychology and religious belief, Blackwell, Oxford. 